\title{
Antioxidant and Photosynthetic Responses in Plants Under Boron Toxicity: A Review
}

\author{
Marco Landi, Elena Degl'Innocenti, Alberto Pardossi and Lucia Guidi \\ Department of Plant Crop Biology, \\ Faculty of Agricultural Science, University of Pisa, Italy
}

Received 2012-05-28; Revised 2012-06-20; Accepted 2012-07-03

\begin{abstract}
Boron (B) is a micronutrient that has long been known essential not only for plants and animals. Otherwise, in crop plants the range of B concentration from essentiality to toxicity appears extremely narrow. Although $\mathrm{B}$ deficiency has been well investigated, during recent years many researchers have also investigated boron toxicity effects, making progress in the comprehension of boron transport within plants. Moreover, worldwide B is not uniformed distributed and, especially in arid and semiarid regions, high B concentrations are found in the soil. Boron in plants primarily moves following transpiration stream even though recent evidences have also confirmed the involvement of B transporter and channel (BOR and NIP). In general, the species that tolerate B excess tends to accumulate less B compared to sensitive species. Likewise other abiotic stresses, antioxidants may be involved in the scavenging of Reactive Oxygen Species (ROS) triggered by B toxicity. Photosynthesis parameters in plants grown under high B supply can draw the photosystems situation and the reactions to B toxicity drawing the healthy status of the plants evaluated. Although boron deficiency has been well investigated, during recent years many researchers have also investigated boron toxicity effects, making progress in the comprehension of boron transport within plants. This review represents the actual state of knowledge concerning B toxicity.
\end{abstract}

Keywords: Reactive Oxygen Species (ROS), Adenosine Triphosphate (ATP), Nicotinamide Adenine Dinucleotide Phosphate (NADPH), Glutathione Reductase (GR)

\section{INTRODUCTION}

\subsection{Chemical Identity of Boron}

Boron is a metalloid element from Group IIIA of the periodic table with an atomic number of 5, an atomic weight of $10.81 \mathrm{~g} \mathrm{~mol}^{-1}$ and an oxidation state of +3 . Boron naturally exists as $19.78 \%{ }^{10} \mathrm{~B}$ isotope and $80.22 \%$ ${ }^{11} \mathrm{~B}$ isotope (WHO, 1998). Boron is electron-deficient, possessing a vacant $p$-orbital; it does not form ionic bonds, but it forms stable covalent bonds. Boron compounds often behave as Lewis acids, readily bonding with electron-rich substances. It has intermediate properties between nonmetals and metals.

Elemental $\mathrm{B}$ naturally occurs and is found in borax ore or tincal $\left(\mathrm{Na}_{2} \mathrm{~B}_{4} \mathrm{O}_{7} \times 10 \mathrm{H}_{2} \mathrm{O}\right)$, boric acid $\left(\mathrm{H}_{3} \mathrm{BO}_{3}\right)$, colemanite $\left[\mathrm{CaB}_{3} \mathrm{O}_{4}(\mathrm{OH})_{3}-\mathrm{H}_{2} \mathrm{O}\right]$, kernite or rasorite $\left(\mathrm{Na}_{2} \mathrm{~B}_{4} \mathrm{O}_{7} \times 4 \mathrm{H}_{2} \mathrm{O}\right)$, ulexite $\left(\mathrm{NaCaB}_{5} \mathrm{O}_{9} \times \mathrm{H}_{2} \mathrm{O}\right)$ and borates (salt or ester of boric acid). Boric acid is the main compound presents at neutral $\mathrm{pH}$ and in this condition it exists as odorless, colorless, translucent crystals or white granules or powder at ambient temperatures (O'Neil et al., 2004). Boric acid is a weak acid with a pKa of 9.2; therefore, in aqueous solution at physiological $\mathrm{pH}$ boric acid primarily exists (more than 98\%) as the undissociated acid $\mathrm{B}(\mathrm{OH})_{3}$, as do borate salts (Tanaka and Fujiwara, 2008).

\subsection{Environmental and Anthropogenic Sources of Boron}

In the environment $\mathrm{B}$ primarily derives from the weathering of minerals containing this element (Kot, 2009). Moreover, geothermal steams significantly contribute to natural occurrence of $\mathrm{B}$ in the environment. High B concentrations, with an average of $4.5 \mathrm{mg} \mathrm{L}^{-1}$ as boric acid, are also recorded in sea water that represents the major source of B contamination in coastal areas due to seawater intrusion into fresh water aquifers. Furthermore, seawater volatilization produces boric acid dissolved in aerosol and boric acid is sometimes found in volcanic spring waters and in the material released by an erupting volcan. Global releases of elemental B through weathering, volcanic and 
geothermal processes are estimated at approximately 360,000 metric tons annually (Moore, 1991).

Sources of B resulting from human activities are less important than natural processes. Anthropogenic sources are as follows: agriculture, waste and fuel wood burning, power generation using coal and oil, glass product manufacture, industrial and household use of borates/perborates, borate mining/processing, leaching of treated wood/paper, sewage and sludge disposal (HSDB, 2003). The principal uses for B compounds in the United States in 2001 were estimated as follows: $78 \%$ glass and ceramics; $6 \%$ soaps and detergents; $3 \%$ agriculture; $4 \%$ flame retardants; and $9 \%$ as other boron compounds (USGS, 2009).

\subsection{Boron Concentration is Extremely Narrow in Soils and Waters}

Boron is an essential micronutrient for crops and its availability in the irrigation water or in the soil represents an important factor for crops production. The range of $\mathrm{B}$ concentrations in soil is extremely narrow (Gupta et al., 1985). In many parts of the world including Japan, China, USA and Brazil, natural B levels are insufficient for crop production since this element is present in the soil as boric acid, which is easily leached out by rainfall due to its high solubility (Bolaños et al., 2004). For this reason, B is frequently added as fertilizer in agricultural systems (Gupta et al., 1985).

On the other hand excess of B may naturally occur in soil or as result of over-irrigation with water rich in B. In arid or semiarid countries, the mainly cause of boron accumulation in the agricultural soil is that the evaporation of groundwater, that reaches the topsoil by capillary. Regions affected by high B level in the soil are in South Australia, Iraq, Egypt, Jordan, Libya, Morocco, Syria, Turkey, Chile and California (You et al., 1995).

\subsection{Boron and Salinity: Which Consequences?}

As mentioned above B toxicity represents an important limiting factor of crop production in many regions of the world. Furthermore, high B concentration is often found in association with high salinity in arid and semiarid environments (Nable et al., 1997). Indeed, simultaneous stress induced by B toxicity and salinity can occur when crop plants either are irrigated with water containing high levels of B and salts or are grown in saline and B-rich soils. Both conditions may occur in semiarid and arid regions characterized by low rainfall and poor drainage (Marschner et al., 1995; Nable et al., 1997). Several researches reported crop responses to the simultaneous excess of B and salinity, for instance in: tomato (Alpaslan and Gunes, 2001; Ben-Gal and Shani, 2002; Guidi et al., 2011), melon (Edelstein et al., 2005), carrot (Eraslan et al., 2007a), bell pepper (Yermiyahu et al., 2008), cucumber (Alpaslan and Gunes, 2001), lettuce (Eraslan et al., 2007b) and spinach (Eraslan et $a l ., 2008)$. In general, it has been reported that combined B toxicity and salinity causes less severe effects on plant growth than what would be expected if the effects of the separate factors were additive. This result was ascribed to a reduction of both $B$ and chloride uptake as a result of antagonism between these two elements (Yermiyahu et al. 2008). It has also been proposed that, under simultaneous presence of B and salt stress, boric acid could affect the activity of specific membrane components (MartinezBallesta et al., 2008). In fact, at high external B levels, significant B transport occurs through the plasma membrane aquaporins (Dordas et al., 2000; Dordas and Brown, 2001). Interestingly, high B and calcium supply enhances crop tolerance to salinity and increases yield in saline soils (El-Hhamdaoui et al., 2003; Bonilla et al., 2004).

Although differences in B tolerance reported for species and cultivars, some general conclusions can be drawn: (i) salinity may reduce B susceptibility in many species through a sort of osmotic protection, that is by reducing the root water uptake that in turn decreases $\mathrm{B}$ accumulation (Ben-Gal and Shani, 2002); (ii) B improves plant response to $\mathrm{NaCl}$ salinity by reducing root uptake and shoot accumulation of $\mathrm{Cl}$ (Yermiyahu et al., 2008); (iii) growth and symptoms due to B toxicity appear reduced under saline conditions (Ben-Gal and Shani, 2002; Yermiyahu et al., 2008).

\subsection{Boron: From Essential to Toxic Element}

In 1923 the essential role of B was demonstrated in Vicia faba (Warington, 1923). Since then, B has been considered an essential micronutrient for plant growth as it plays an important role in many metabolic processes (Marschner et al., 1995; Goldbach et al., 2001; O'Neill et al., 2004). Boron is essential not only for plants, algae, cyanobacteria, diatoms also required an adequate concentration of this element to their development (Loomis and Durst, 1992) and also animals such as trout and frog (Rowe and Eckhert, 1999). Deprivation of B in animals can influence their growth due to an inadequate bones development or it can cause others micronutrient-dependent effects. However, its essentiality for human has not been established. On the other hand, it seems established that excessive $\mathrm{B}$ intake can be responsible for weight loss and anorexia, diarrhea, neurological and cardiovascular effects reported in mice and rats. Furthermore, $\mathrm{B}$ can also cause malformations at skeletal and cardiovascular level on fetal body in pregnant animals (Yazbeck et al., 2005). For this reason the European Food Safety Authority (EFSA, 2004) has established a Maximum daily B Intake (MDI) of $10 \mathrm{mg}$ for adult people considering that the main sources of $\mathrm{B}$ in human diet are fruits, vegetables and drinking water (Tanaka and Fujiwara, 2008). In many regions of the world, $\mathrm{B}$ concentration in groundwater can be as high as 3-13 $\mathrm{mg}$ $\mathrm{L}^{-1}$ thus exceeding the maximum acceptable $\mathrm{B}$ concentrations established for drinking water in some countries (Table 1). 
Table 1. Maximum acceptable concentrations for boron in drinking water (Kot, 2009), Reference in the Table are in Kot (2009)

\begin{tabular}{lll}
\hline $\begin{array}{l}\text { Country/ } \\
\text { organisation }\end{array}$ & $\begin{array}{l}\text { concentration } \\
\left(\mathrm{mg} \mathrm{L}^{-1}\right)\end{array}$ & Reference \\
\hline Canada & 5.0 & Health Canada (2006) \\
European Union & 1.0 & Weinthal et al. (2005) \\
Russia & 0.5 & SanPiN (2001) \\
USA & 0.3 & EPA (1996) \\
WHO & 0.3 & WHO (1998) \\
\hline
\end{tabular}

Concerning plants, excess of B exerts different effects such as: reduced root cell division, lower leaf chlorophyll contents and photosynthetic rates; decreased levels of lignin and suberin, among others (Nable et al., 1997; Reid, 2007). Accordingly, a reduced growth of both shoot and root is typical of plants exposed to high B levels (Nable et al., 1990). Although the physiological basis for B toxicity are not clear, three main causes have been hypothesized considering the B chemistry: (i) alteration of cell wall structure; (ii) metabolic disruption by binding to the ribose moieties of molecules such as Adenosine Triphosphate (ATP), Nicotinamide Adenine Dinucleotide (NADH) or Nicotinamide Adenine Dinucleotide Phosphate (NADPH); (iii) disruption of cell division and development by binding to ribose, either as the free sugar or within RNA (Reid et al., 2004). Although growth was rapidly inhibited by internal B concentrations in the range $1-5 \mathrm{~mm}$, this inhibition was not attributable to the effects of B on either energy supplies or inhibition of protein synthesis, but the toxicity to mature tissues was rather due to the accumulated retardation of many cellular processes, enhanced in light by photooxidative stress (Reid et al., 2004).

Boron was found to inhibit one step of in vitro premRNA splicing reaction (Shomron and Ast, 2003), which suggests that B toxicity is primarily due to disruption of RNA splicing (Reid, 2007). Interestingly, several genes that encode transcription factors of ribosomal proteins conferred B tolerance in lupin (Lupinus albus) and Arabidopsis thaliana (Reid, 2007) as well as in yeast (Nozawa et al., 2006). These proteins could act as splicing sites protectors from B bound, thus suggesting the occurrence of a mechanism that confers genuine $\mathrm{B}$ tolerance other than the ability to efflux B from the cells (Reid, 2007).

\subsection{Different Susceptibility to Boron Toxicity}

In plants, the range between optimal and toxic B concentrations is extremely narrow (Gupta et al., 1985). Plants tolerance to B toxicity is widely variable from species to species and even among varieties of the same species. For instance, safe B concentrations in irrigation water range from $0.3 \mathrm{mg} \mathrm{L}^{-1}$ for sensitive plants (e.g., Phaseolus vulgaris) to $1-2 \mathrm{mg} \mathrm{L}^{-1}$ for semi-tolerant plants (e.g., Zea mays and Solanum tuberosum), 2-4 $\mathrm{mg} \mathrm{L}^{-1}$ for tolerant plants (e.g., Daucus carota and Cuminos melo) and 4-6 $\mathrm{mg} \mathrm{L} \mathrm{L}^{-1}$ for high tolerant plants such as Solanum lycopersicon (Nable et al., 1997). In general, B tolerant species can better survive to other salt stress (e.g., $\mathrm{NaCl}$ salinity) compared to sensitive plants. Moreover, within the same species more tolerant varieties have an endogenous B concentration lower than less tolerant varieties (Nable et al., 1997; Cervilla et al., 2007; 2012). This behavior appears to be related to the plant's ability to exclude B at root level: a reduced permeability of membrane lipids and/or the presence of carriers (BOR and NIP) essential for B extrusion from the cytoplasm may be responsible for reduced B accumulation (Miwa et al., 2007; Sutton et al., 2007).

\subsection{Boron: From Roots to Leaves}

\subsection{Uptake and Translocation Following Transpiration Stream}

Boron uptake is considered to be a passive process: It is absorbed from the soil by roots mainly as not dissociated boric acid $\left(\mathrm{H}_{3} \mathrm{BO}_{3}\right)$ and then transported to the leaves via the xylem. This is partly due to the high permeability of boric acid to lipid bilayers (Brown and Shelp, 1997; Dordas and Brown, 2001).

In plants, the long distance translocation of nutrient elements takes place in the vascular system consisting of the xylem and phloem. Upward movement from the roots to the shoots occurs in the nonliving cells of the xylem and this process is mainly driven by the gradient in water potential resulting from surface transpiration during the day. Thus, xylem translocation is mainly directed to the mature leaves because they represent the sites with the highest transpiration and, at the same time, they are sites with the lowest demand for nutrients (Pate, 1975).

In contrast, long distance translocation in the phloem, composed by living cells, occurs in both upward and downward directions. Phloem translocation does not follow transpiration stream and supplies the major proportion of nutrient requirements for actively growing areas, such as young leaves, fruits and seeds; all these organs do not readily transpire (Brown and Shelp, 1997). It has generally been accepted that $B$ is an immobile nutrient in the phloem tissues and therefore tends to accumulate in highly-transpiring mature leaves. Kohl and Oertli (1961) demonstrated that B uptake followed the passive water flux from roots to leaves accumulated especially where termination of leaf veins terminate; these tissues show more evident symptoms of B toxicity such as chlorosis and necrosis. According to the previous hypothesis, higher B concentrations were found in leaf tissues than in phloem sap (Shelp, 1987; 1988). Moreover, since B is not efficiently remobilized, the 
symptoms of B deficiency and toxicity occur in young and mature organs, respectively.

\subsection{Evidence of Boron in Phloem Tissues}

Recent findings suggest that the passive mechanism could not be the only mechanism involved in B translocation and tolerance to B toxicity (ChamachoCristobal et al., 2008). Brown and Shelp (1997) showed that in some plant species B can be redistributed within the plant and the extent of $\mathrm{B}$ phloem mobility significantly varies among plant species. In many plants, including many important crop and tree species (e.g., Pyrus, Malus, Prunus, Allium and Brassica), B was found to be uniformly distributed under B deficiency (Brown and $\mathrm{Hu}$, 1996); moreover, it was found that B concentration in young leaves was higher compared to mature leaves.

While in plants with low B mobility, the typical symptoms are chlorotic and/or necrotic patches (burn) of the older leaves where B tends to accumulate (Nable et al., 1997), in plant species where B translocation occurs, the symptoms of B toxicity firstly appear in the meristemic regions and fruits and do not occur in mature leaves (Brown and $\mathrm{Hu}, 1996$ ). Because this pattern of distribution cannot be explained by B distribution along transpiration stream, other possible mechanisms were suggested. These species commonly produce relatively high amounts of sugar alcohols (e.g., mannitol and sorbitol) which are used for the phloem translocation of photosynthates in place of sucrose (Brown et al., 1999). Polyols, such as sorbitol and mannitol, contain cis-hydroxyl groups that can readily bind to boric acid originating diol-boron complexes; this binding is likely to allow B to be transported through phloem. Hu et al. (1997) showed that B was present as a stable polyol-B complex with mannitol and sorbitol as ligands. Furthermore, plants with high ability to produce sugar alcohols can better tolerate B deficiency than plants with a lower capacity. Transgenic tobacco plants transformed with the sorbitol synthesizing enzyme had higher growth and yield under B starvation compared with wild type (Brown et al., 1999). It was argued that the transgenic lines had higher ability in B remobilization through phloem than control plants suggesting that B can move along the flow of Bbinding sugar alcohol (Brown et al., 1999).

Takano et al. (2001) found that B was transported via phloem in young leaves also in plants do not produce sugar alcohols, thus suggesting an alternative mechanism of translocation (Takano et al., 2001). In these plants including Arabidopsis thaliana (Takano et al., 2001) and Brassica napus (Stangoulis et al., 2001), the translocation was reported under B limitation, but not in conditions of normal or luxury B supply. In fact, Tanaka and Fujiwara (2008) showed that an active B transport occurred in plants due to channels and transporters (BOR and NIR); this type of transport is probably enhanced under B deficiency. Since translocation occurs only under B limitation, this suggests that plants are capable of sensing B levels in the growing medium and within plant tissues. Consequently, they are able to regulate both root uptake and vascular movement of $B$. This regulation is essential to survive under conditions of limited B supply.

\subsection{Proposed Mechanisms to Explain Boron Mobility}

Several mechanisms are involved in B translocation. The passive diffusion across lipid membranes is mainly due to the high permeability coefficient of boric acid for lipid bilayer and, in the presence of excess B, it represents the main pathway for B transport (Tanaka and Fujiwara, 2008).

On the other hand, under conditions of limited B supply, other mechanisms are necessary to transport B against its concentration (Dannel et al., 2000). BOR1 was the first B transporter found in Arabidopsis and it was shown essential under low B supply (Takano et al., 2002). BOR 1 is regulated at post-transcriptional level and the protein is degraded under adequate or luxury B supply suggesting a sophisticated regulation of this pathway in order to maintain a constant B uptake under variable growing conditions (Noguchi et al., 2003; Takano et al., 2002; 2005). However, these results suggest that BOR1 is not involved in B tolerance.

Nevertheless, an independent transgenic $A$. thaliana line has been generated showing that BOR4, another efflux-type borate transporter, is not degraded at the post-transcriptional level as occurs with BOR1. Accumulation of BOR4-GFP (Green Fluorescence Protein) and tolerance of B were positively correlated and the overproduction of BOR4-GFP improved plants growth under high B levels through boron efflux.

Furthermore, Takano et al. (2006) reported that also another channel, NIP5 was required to Arabidopsis to grown under low B supply. NIP5 belongs to Major Intrinsic Protein (MIPs) including aquaporine and it was supposed that this channel was a B importer at root level after the evidence that NIP5-deficient plants had a lower B concentration in roots and a reduced shoots elongation only under low B supply (Takano et al., 2006). At present, nine NIPs have been reported in Arabidopsis (Takano et $a l ., 2006)$ and other members of this family are probably involved in this sophisticate pathway.

\subsection{Can Antioxidants Increase Boron Tolerance in Plants?}

When plants are subjected to environmental stress conditions such as high light intensity, extreme temperatures, drought, high salinity, herbicide treatment, or mineral disorders, the balance between the production of ROS and the quenching activity of the antioxidants is upset, often resulting in oxidative damage (Wise and 
Naylor, 1987; Mittler, 2002). Plants with high levels of antioxidants, either constitutive or induced, have been reported to have a great resistance to this oxidative damage (Dhindsa and Matowe, 1981; Wise and Naylor, 1987; Foyer and Shigeoka, 2011).

Glutathione (GSH) and ascorbate (AsA) are well known antioxidant compounds with recognized radicals scavenging activity even though an increasing number of evidences confirms that other molecules, such as phenols, anthocyanins and flavonoids, can increase antioxidant ability in many plant species especially herbaceous (Zheng and Wang, 2001; Javanmardi et al., 2002; Shan et al., 2005; Surveswaran et al., 2007; Lee and Scagel, 2009). In plants, polyphenolic compounds are typically produced to protect plants against pests and diseases (Herms and Mattson, 1992; Crozier et al., 2006; Mullen et al., 2007), nutrient stress (Herms and Mattson, 1992) and exposure to UV radiation (Rozema et al., 1997). Moreover, anthocyanins, which are responsible for the primary red and blue pigments in plants, have been recognized as contributing to plant growth, protection and development (Holton and Cornish, 1995) and as powerful antioxidant (Tsuda et al., 1996; Gould et al., 2002).

Non-enzymatic antioxidants are represented by enzymes such as, Catalase (CAT), Superoxide Dismutase (SOD), guaiacol Peroxidase (POD) and enzymes directly involved in Halliwell-Asada cycle: Ascorbate Peroxidase (APX) Glutathione Reductase (GR), Monodehydroascorbate Reductase (MDHAR), Dehydroascorbate Reductase (DHAR) (Melgar et al., 2009).

It is really important for plants survival under stress conditions that these antioxidants act synergistically and cooperatively, thus providing better defense and regeneration of the active reduced forms. The most studied example of the antioxidant network is the ascorbate-glutathione (Halliwell-Asada) pathway in the chloroplasts, where it provides photoprotection by removing $\mathrm{H}_{2} \mathrm{O}_{2}$ (Noctor and Foyer, 1998) (Fig. 1). Components of this cycle have been detected in other cell compartments (Jimenez et al., 1998).

Ascorbate works in co-operation not only with glutathione, but also takes part in the regeneration of $\alpha$-tocopherol, providing synergetic protection of the membranes (Asensi-Fabado and Munné-Bosch, 2011). Tocopherol has been reported to be in direct interaction also with reduced glutathione (Fryer, 1992) and reduced coenzyme Q (Buettner, 1993). Kagan et al. (2000) suggested that tocopherol and reduced coenzyme Q, when they are both present in a membrane, showed combined antioxidant activity. Recently, redox coupling of plant phenolics with ascorbate in the $\mathrm{H}_{2} \mathrm{O}_{2}$-peroxidase system has been shown (Takahama and Oniki, 1997; Yamasaki and Grace, 1998; Ferreres et al., 2011). It takes place in the vacuole, where $\mathrm{H}_{2} \mathrm{O}_{2}$ diffuses and can be reduced by peroxidases using phenolics as primary electron donors. Both AsA and the Monodehydroascorbic Acid Radical (MDHA) can reduce phenoxyl radicals generated by this oxidation. If regeneration of AsA is performed in the cytosol and AsA is supplied back to the vacuole, a phenolics and/or AsA peroxidas system could function in vacuoles and scavenge $\mathrm{H}_{2} \mathrm{O}_{2}$. This mechanism is specific for plant tissues and can improve stress tolerance under oxidative stress (Yamasaki and Grace, 1998).

\subsection{Ascorbic Acid}

AsA is considered one of the strongest molecules among antioxidants (Noctor and Foyer, 1998; Smirnoff et al., 2001). Under physiological conditions AsA mostly exists in the reduced form ( $90 \%$ of the ascorbate pool) in leaves and chloroplasts (Smirnoff, 2000) and its intracellular concentration can build-up to millimolar range (e.g., $20 \mathrm{mM}$ in the cytosol and $20-300 \mathrm{mM}$ in the chloroplast stroma; Foyer and Lelandais, 1996). Evidences showed that AsA can directly scavenge hydroxyl and superoxide radicals, singlet oxygen; moreover, it can reduce $\mathrm{H}_{2} \mathrm{O}_{2}$ to water via ascorbate peroxidase reaction (Noctor and Foyer, 1998). AsA also acts as a cofactor of violaxantin de-epoxidase thus sustaining dissipation of excess excitation energy (Smirnoff, 2000) and can provide to tocopherol regeneration from tocopheroxyl radical providing membrane protection (Thomas et al., 1992). The role of AsA in the plant's response to B toxicity is not simple to draw due to the limited number of studies on this topic.

$B$ can significantly influence the plant ability to produce many compounds (including AsA) (Gunes et al., 2006; Eraslan et al., 2008). Singh et al. (2012) found variable levels of AsA production in different carrot genotypes; the level were higher under B deficiency rather than under $B$ toxicity. We similarly found different reactions concerning the AsA levels in different cultivars of sweet basil (Ocimum basilicum; cv. Tigullio, green-leaved and cv. Red Rubin, purple-leaved) grown with excess B in the growing medium. In fact, in leaves of Tigullio plants an increase in AsA content was recorded; on the other hand, Red Rubin cultivar showed a decrease of this compound (unpublished results). More uniform was the trend of AsA reported by Cervilla et al. (2007) in two tomato (Solanum lycopersicon) cultivars (Josefina and Kosaco) grown with B in the nutrient solution. Both cultivars showed a general stimulation of antioxidants, including AsA. However, it is remarkable that the cultivar Josefina showed, at the same time, the lower B uptake in leaves and the higher AsA content compared to the cultivar Kosaco. A similar increase in AsA concentration was found in potato eaves (Mondy and Munshi (1993) and in orange (Citrus grandis) leaves Keles et al. (2004) after high B foliar supply. On the other hand, a decrease in AsA amount was reported by 
Eraslan et al. (2007a) in both leaves and roots of carrot grown with $5 \mu \mathrm{M}$ of $\mathrm{B}$ in the nutrient solution. When the plants were simultaneously treated with $\mathrm{B}$ and and $\mathrm{Na}_{2} \mathrm{SO}_{4}$ the concentration of AsA significantly increased. Similar results were found in lettuce (Eraslan et al., 2007b): in this experiment the AsA concentration recorded in plants grown under $\mathrm{B}$ or $\mathrm{NaCl}$ stress was not significantly different from control plants while AsA increased as result of combined $\mathrm{NaCl}$ and $\mathrm{B}$ supply.

It is notable that AsA amount decreased in species and/or cultivar with high APX activity and then large AsA consumption compared to plant genotypes where APX plays a minor role in ROS scavenging. Eraslan et al. (2007a) in carrot and Han et al. (2009) in citrus recorded that high $\mathrm{B}$ concentration reduced AsA concentration while increasing APX activity. In contrast, in lettuce B increased APX activity compared to control plants while not significant differences were recorded in AsA concentration (Eraslan et al., 2007b).

\subsection{Gluthatione}

A tripeptide glutathione ( $\gamma$-glutamylcysteinylglycine) is an abundant compound in plant tissues. It has virtually been found in all cell compartments: cytosol, endoplasmic reticulum, vacuole and mitochondria where GSH executes multiple functions (Jimenez et al., 1998). GSH is the main storage form of sulfur acts as a potent detoxifier of xenobiotics through GSH-conjugation and can represent as a precursor of phytochelatins (reviewed by Noctor et al., 1998; May et al., 1998). Together with its oxidized form (GSSG), glutathione maintains a redox balance in the cellular compartments. This property is of great biological importance, since it allows fine-tuning of the cellular redox environment under both optimal and stress conditions and provides the basis for GSH stress signaling. Indeed, the role for GSH in redox regulation of gene expression has been described in many papers (e.g., Wingate et al., 1988; Alscher, 1989). Due to redox properties of the GSH/GSSG pair and reduced SH-group of $\mathrm{GSH}$, it can participate in the regulation of the cell cycle (Sanchez-Fernandez et al., 1997).

Functioning of GSH as antioxidant under oxidative stress has received much attention during the last decades. A central nucleophilic cysteine residue is responsible for high reductive potential of GSH. It scavenges cytotoxic $\mathrm{H}_{2} \mathrm{O}_{2}$ and reacts non-enzymatically with other ROS: superoxide radical, singlet oxygen and hydroxyl radical (Larson, 1988; Shao et al., 2008). The central role of GSH in the antioxidative defence is due to its ability to regenerate ascorbic acid via the ascorbate-glutathione cycle (Foyer and Noctor, 2011) how mentioned above. Thus, the evaluation of its content and its redox status can be useful to understand the non-enzymatic antioxidant system reaction under several stresses (Ryang et al., 2009).

In sunflower Ruiz et al. (2003) reported that B excess inhibited glutathione synthesis where as an external application of this antioxidant reduced damages induced by B toxicity. Moreover, LeNoble et al. (1996) and Ruiz et al. (2006) showed that B reduces Al phytotoxicity by stimulating GSH biosynthesis in the leaves and the increase in its concentration in the roots, where it could prevent injuries due to ROS accumulation. This study indicates the crucial role of GSH metabolism for $\mathrm{Al}$ detoxification. Notable was a simultaneous increase of total GSH and AsA recorded under B-deficiency in citrus plants while both these molecules decreased under B-excess condition (Han et al., 2009). These results are partially in accord with Wang et al. (2011) who also reported an increase in total GSH content in pear leaves under high boron supply.

\subsection{Phenols}

Phenolics represent a large class of secondary metabolites (flavonoids, anthocyanins, tannins, hydroxycinnamate esters and lignin) abundant in plant tissues (reviewed by Grace and Logan, 2000). Antioxidative properties of polyphenols arise from: (i) high reactivity as hydrogen or electron donors; (ii) the ability of the polyphenol-derived radical to stabilize and delocalize the unpaired electron due to their chemistry structural (chain-breaking function); (iii) the ability to chelate transition metal ions (termination of the Fenton reaction) (iv) the ability of flavonoids to alter peroxidation kinetics by modification of the lipid packing order and to decrease fluidity of the membranes (Arora et al., 2000). These changes could sterically hinder diffusion of free radicals and restrict peroxidative reactions. Moreover, it has recently been shown that phenolic compounds can be involved in the hydrogen peroxide scavenging cascade in plant cells (Takahama and Oniki, 1997; Dangles, 2012). An antioxidant role of flavonoids compounds has been reported due to their molecular structure (Pourcel et al., 2006; Hernandez et al., 2009; Agati and Tattini, 2010).

There is evidence that $\mathrm{B}$ is one of the nutrients responsible for the changes in concentration and metabolism of phenolic compounds in vascular plants, since B deficiency causes an accumulation of phenolics (Cakmak and Romheld, 1997). However, little information is available about phenols reaction under B stress. Ruiz et al. (1998) and Chamacho-Cristobal et al. (2002) reported an increase in phenolic content in the leaves of tobacco plants grown both under B deficiency or toxicity. Boron forms complexes ( $>90 \%$ of the foliar content) mainly with pectins and phenols in the cell wall and plasma membrane, respectively, resulting in higher stability of these structures. When B supply is adequate more than $60 \%$ of this element is in free form in leaves tissues (Brown and $\mathrm{Hu}, 1996$ ). In view of above, in conditions of B excess phenols may play a role in $\mathrm{B}$ compartmentalization rather than in antioxidant activity.

During the last years anthocyanins, a particular group of phenols, have received great attention due to the 
evidence of plant antioxidant capacity is related to the content of these compounds (Tsuda et al., 1996; Gould et $a l ., 2002)$. The antioxidant activity of anthocyanins might be mainly due to their strong redox properties, which allow them to act as reducing agents, hydrogen donators and singlet oxygen quenchers. It has also been suggested that the increase in anthocyanins level under salt stress is mainly due to their photoprotection of chlorophylls (Gould et al., 2000). Moreover, anthocyanins are thought to be involved in osmotic regulation (Chalker-Scott, 2002). Many studies reported that plant tissues rich in anthocyanins are generally relatively resistant to drought and salt stresses (ChalkerScott, 1999). A purple-leaved of pepper tolerated salt stress better than a green-leaved cultivar (Bahler et al., 1991). The highly drought and salt tolerant resurrection plant Craterostigma plantagineum contained higher amount of anthocyanins during dehydration as compared to the hydrated stage (Sherwin and Farrant, 1998). Eraslan et al. (2008) showed an increase of anthocyanins concentration in Spinacia oleraceae grown under conditions of B excess and salt stress.

\subsection{Antioxidant Enzymes}

Boron stress causes an oxidative stress because of the formation of ROS such as superoxides and hydroxy and peroxy radicals as occur in many other ionic stress. The ROS that are by-products of hyperosmotic and ionic stresses cause membrane disfunction and cell death (Bohnert and Jensen, 1996). Generally, the plants defend against these ROS by induction antioxidative enzymes such as catalase, peroxidase, glutathione reductase and superoxide dismutase, which scavenge ROS (Table 2).

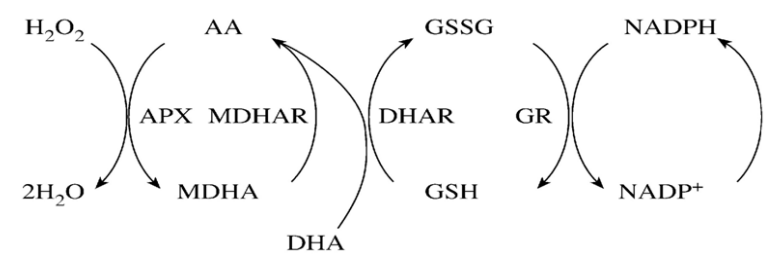

Fig. 1. Ascorbate-glutathione cycle (Halliwell-Asada). APX, ascorbate peroxidase; MDHAR, monodehydroascorbate reductase; DHAR, dehydroascorbate reductase; GR, glutathione reductase

Table 2. The major ROS scavenger and antioxidant enzymes

\begin{tabular}{lll}
\hline Enzyme & EC & Reaction Catalysed \\
\hline SOD & 1.15 .1 .1 & $\mathrm{O}_{2}{ }^{-}+\mathrm{O}_{2}{ }^{-}+2 \mathrm{H}^{+} \Leftrightarrow 2 \mathrm{H}_{2} \mathrm{O}_{2}+\mathrm{O}_{2}$ \\
CAT & 1.11 .1 .6 & $2 \mathrm{H}_{2} \mathrm{O}_{2} \Leftrightarrow \mathrm{O}_{2}+2 \mathrm{H}_{2} \mathrm{O}$ \\
APX & 1.11 .1 .11 & $\mathrm{AA}+\mathrm{H}_{2} \mathrm{O}_{2} \Leftrightarrow \mathrm{DHA}+2 \mathrm{H}_{2} \mathrm{O}$ \\
MDHAR & 1.6 .5 .4 & $\mathrm{NADH}+2 \mathrm{MDHA} \Leftrightarrow \mathrm{NAD}^{+}+2 \mathrm{AA}$ \\
DHAR & 1.8 .5 .1 & $2 \mathrm{GSH}+\mathrm{DHA} \Leftrightarrow \mathrm{GSSG}+\mathrm{AA}$ \\
GR & 1.6 .4 .2 & $\mathrm{NADPH}+\mathrm{GSSG} \Leftrightarrow \mathrm{NADP}^{+}+2 \mathrm{GSH}$ \\
\hline
\end{tabular}

There are several reports of increasing activity of antioxidative enzymes under high B supply (Gunes et al., 2006; Cervilla et al., 2007; Eraslan et al., 2007a; Ardic et al., 2009; Wang et al., 2011). SOD is the major $\mathrm{O}_{2}^{--}$ scavenger and its enzymatic action results in $\mathrm{H}_{2} \mathrm{O}_{2}$ and $\mathrm{O}_{2}$ formation. The $\mathrm{H}_{2} \mathrm{O}_{2}$ produced is then scavenged by CAT and several classes of peroxidases. Catalase, which is found in peroxisomes, cytosol and mitochondria, dismutates $\mathrm{H}_{2} \mathrm{O}_{2}$ into $\mathrm{H}_{2} \mathrm{O}$ and $\mathrm{O}_{2}$ (Mittler, 2002). Peroxidases (APX and GPX) are distributed throughout the cell and catalyze the reduction of $\mathrm{H}_{2} \mathrm{O}_{2}$ to $\mathrm{H}_{2} \mathrm{O}$. APX uses ascorbate as electron donor in the first step of the ascorbate-glutathione cycle and it is considered the most important plant peroxidase for $\mathrm{H}_{2} \mathrm{O}_{2}$ detoxification (Noctor and Foyer, 1998). GR, MDHAR and DHAR are involved in Halliwell-Asada cycle (Fig. 1) and their activities might influence the turn-over of reduced ascorbate regeneration. Moreover, recent researches have shown that over-expression of MDHAR can increase the amount of reduced ascorbate because MDHAR functions upstream of DHAR in the ascorbate recycling pathway (Ishikawa et al., 2006).

SOD is responsible for the detoxification of $\mathrm{O}_{2}^{-}$by forming $\mathrm{H}_{2} \mathrm{O}_{2}$, which also being toxic must be eliminated by conversion to $\mathrm{H}_{2} \mathrm{O}$ in subsequent reactions. Superoxide radicals $\left(\mathrm{O}_{2}^{-}\right)$are toxic byproducts of oxidative metabolism and can interact with $\mathrm{H}_{2} \mathrm{O}_{2}$ to form highly reactive hydroxyl radicals $\left(\mathrm{OH}^{-}\right)$, which are thought to be primarily responsible for oxygen toxicity in the cell (Mittler, 2002; Azevedo-Neto et al., 2006). Generally, SOD activity increased during high B supply (Garcia et al., 2001; Gunes et al., 2006; Molassiotis et al., 2006; Sotiropoulos et al., 2006). For instance, Cervilla et al. (2007) observed an increase of SOD activity only in tomato cultivar Kosaco plants grown at 0.5 and $2.0 \mathrm{mM}$ of B (compared to the control level). In contrast, Josefina cultivar plants grown in the same condition exhibited an upgrade of SOD activity only at $0.5 \mathrm{mM}$ of $\mathrm{B}$. At the highest $\mathrm{B}$ concentration SOD activity did not significantly change compared to the control. An increased in SOD activity was also reported in tomato grown with $2 \mathrm{mg} \mathrm{L^{-1 }}$ of $\mathrm{B}$ in the nutrient solution by Kaya et al. (2009). Moreover, an increase in SOD activity was reported by Han et al. (2009) in citrus leaves both under B deficiency and excess and by Ardic et al. (2009) in two chickpea cultivars submitted to 1.6 and $6.4 \mathrm{mM}$ of $\mathrm{B}$ in comparison to control plants $(0.05 \mathrm{mM})$. Moreover, Ardic et al. (2009) reported that the increase in SOD activity was due to the induction of new isoforms of the enzyme rather than an increase of constitutive isoenzymes. Thus, the authors hypothesized that SOD is tightly controlled in response to B excess according to other researches (Garcia et al., 2001; Karabal et al., 2003). 
The oxidative stress triggered by B toxicity increases $\mathrm{O}_{2}^{-}$production and, consequently, SOD activity. For this reason the reaction catalyzed by this enzyme can play an important role in radicals scavenging but, at the same time, other enzymes are necessary to scavenge the hydrogen peroxide generate by SOD. In plants, a number of enzymes regulate $\mathrm{H}_{2} \mathrm{O}_{2}$ intracellular levels, but CAT and APX are considered the most important ones (Noctor and Foyer, 1998) and certain concentrations of $\mathrm{H}_{2} \mathrm{O}_{2}$ can promote CAT and APX activity (Bowler et al., 1992). For instance, in pear Wang et al. (2011) reported an increase in the activity of these two antioxidant enzymes and a strongly $\mathrm{H}_{2} \mathrm{O}_{2}$ accumulation at 100 and $300 \mu \mathrm{M}$ of $\mathrm{B}$ compared to control plants grown at $10 \mu \mathrm{M}$. On the other hand, in the same research, plants grown at $500 \mu \mathrm{M}$ of B showed lower APX and CAT activity. The authors hypothesized that the accumulation of $\mathrm{O}_{2} \cdot{ }^{-}$and $\mathrm{H}_{2} \mathrm{O}_{2}$ exceeded the scavenging ability and consequently ROS could be accumulates and causes lipid peroxidation and membrane damage. The increase in CAT was observed in many species exposed to B excess (Gunes et al., 2006; Molassiotis et al., 2006; Cervilla et al. 2007; Ardic et al., 2009; Soylemezoglu et al., 2009). Conversely, Keles et al. (2004) and Han et al. (2009) reported a decrease in CAT activity in citrus leaves due to B toxicity. Interestingly, Han et al. $(2008$; 2009) reported a concomitant buildup of APX activity under both conditions of limited and excessive B supply and suggested that in this species APX plays a major role in $\mathrm{H}_{2} \mathrm{O}_{2}$ scavenging than CAT. In agreement with these results (Eraslan et al., 2007b), a strong CAT increase and a concomitant decrease in APX activity under B stress were observed in Vitis (Gunes et al., 2006) and in lettuce under B stress. The increase of CAT activity was also recorded in tomato (Cervilla et al., 2007), tobacco (Garcia et al., 2001), hot pepper (Lee, 2006), pear (Wang et al., 2011).

Furthermore, exposing plants to simultaneous B and other salt stress as Si (Gunes et al., 2006) and $\mathrm{NaCl}$ (Eraslan et al., 2008) a mitigation of the activity of APX and CAT was recorded as compared to the values found in plants treated only with B.

Since AsA is believed to play a great important role in the antioxidant response to many stresses, the regeneration of this molecule is also a relevant process. This pathway involves the enzymes GR, MDHAR, DHAR which are distributed in most cellular compartments (Ishikawa et al., 2006). In general, their activity is enhanced by B toxicity (Cervilla et al., 2007; Lopez-Gomez et al., 2007; Wang et al., 2011). On the contrary, under conditions of severe B toxicity, ROS production exceeds the ability of these enzymes to reduce DHA in to AsA (Wang et al., 2011). Moreover, GR was stimulated by B toxicity in barley (Karabal et al., 2003), citrus (Han et al., 2009) and the cultivar Gökce of chickpea (Cicer arietinum) (Ardic et al., 2009). On the contrary, a decrease of GR was recorded in another cultivar (Küsmen) of chickpea (Ardic et al., 2009). In citrus leaves the activity of all of three enzymes was enhanced under B deficiency while excess B stimulated only the activity of GR (Han et al., 2009). It is remarkable that B deficiency also increased the content of AsA and GSH while in plants subjected to B toxicity the amount of these two antioxidants decreased. This suggests that GR, MDHAR and DHAR are involved and necessary to promote an adequate turn-over of AsA and GSH regeneration.

Over-expression of MDHAR affected ascorbate accumulation and increased the redox status of this molecule toward reduction (Ishikawa et al., 2006). Indeed, MDHAR functions upstream of DHAR in the ascorbate recycling pathway.

\subsection{Effects of Boron on Photosynthesis}

Information on the effects of B on photosynthetic process is still scarce even if it has known that boron excess inhibits photosynthesis (Han et al., 2008; 2009; Ardic et al., 2009; Guidi et al., 2011; Chen et al., 2012). Experimental data are sometimes contradictory. In condition of $\mathrm{B}$ toxicity, $\mathrm{CO}_{2}$ assimilation decreased in many species such as summer squash (Lovatt and Bates, 1984), kiwifruit (Sotiropoulos et al., 2002), Clementine mandarin (Papadakis et al., 2004a), citrus (Papadakis et al., 2004b; Han et al., 2009; Sheng et al., 2010) and pear (Wang et al., 2011).

It has well known as the lower $\mathrm{CO}_{2}$ assimilation in $\mathrm{B}$ deficient leaves is related to stomatal factors (Papadakis et al., 2004a; Han et al., 2009; Sheng et al., 2009). Conversely, the reduction in $\mathrm{CO}_{2}$ assimilation under $\mathrm{B}$ excess conditions seems to be related to a combination of different factors: oxidative load, decrease in photosynthetic enzymatic activities and an impaired electron transport rate (Han et al., 2009). However, the mechanisms involved in the alteration of photosynthesis by B stress has not be elucidated yet.

Some authors found that the reduction in photosynthetic rate in plant subjected to $\mathrm{B}$ excess was accompanied by an increase in intercellular $\mathrm{CO}_{2}$ concentration whereas stomatal conductance remained unaffected (Sotiropoulos et al., 2002). In contrast, other authors observed a reduction in stomatal conductance (Lovatt and Bates, 1984; Papadakis et al., 2004a). Pereira et al. (2000) hypothesized that one of the possible reasons for the reduction of photosynthesis by B excess was the structural damage of thylakoids; this, in turn, altered the rate of electron transport and influenced $\mathrm{CO}_{2}$ photoassimilation which can also be limited by stomatal reduction.

The $\mathrm{F}_{\mathrm{v}} / \mathrm{F}_{\mathrm{m}}$ ratio (maximum quantum yield of chlorophyll fluorescence) significantly decreased in many species following B toxicity (Larsson et al., 1998; Papadakis et al., 2004a; 2004b; Guidi et al., 2011). The 
reduction of $\mathrm{F}_{\mathrm{v}} / \mathrm{F}_{\mathrm{m}}$ is sometimes related to an increase in $\mathrm{F}_{0}$ (minimal chlorophyll fluorescence) which is closely related to the structural damage to the thylakoid membranes (Havaux and Lannoye, 1985). It is clear that the decrease in $\mathrm{F}_{\mathrm{v}} / \mathrm{F}_{\mathrm{m}}$ ratio indicates that leaves are photoinhibited and it has well known as in these conditions molecular oxygen can represent an alternative electron acceptor for unused electrons and light (VelezRamirez et al., 2011), which leads to the generation of ROS. This event can also explain the observed decrease in chlorophyll content leaves (Papadakis et al., 2004b; Han et al., 2009; Chen et al., 2012) and chloroplast damage (Papadakis et al., 2004; 2004b) in plants grown under conditions of B toxicity. Papadakis et al. (2004a) reported that leaves of Clementine orange treated with $\mathrm{B}$ excess showed a decrease in their thickness and a disorganization of mesophyll cells. Similar results were found by Sotiropoulos et al. (2002) in kiwifruit and by Kamali and Childers (1967) in peach. Thus, B excess can induce an alteration of leaf structure both in the species where $\mathrm{B}$ is phloem immobile (orange and kiwifruit) and in those where B mobility is high as peach (Brown and Shelp, 1997).

On the other hand, Guidi et al. (2011) found that a reduction of electron transport rate induced by boron excess attributable to an increase in $\mathrm{J}_{\mathrm{NPQ}}$, the quantum yield of excitation energy thermally dissipated. It has known that the loss of excitons through non-radiative decay in PSII is a down-regulated process and that leaves can alleviate the damage to photosynthetic processes by dissipating the excessive excitation energy into harmless heat (Kramer et al., 2004). This hypothesis was substantiated by the higher values of $\mathbf{J}_{\mathrm{NPQ}}$ found in central and asymptomatic leaf portions compared to the necrotic margins. However, boron toxicity also induced a decrease in the fraction of open PSII reaction centers and a slow re-oxidation of QA due to the inhibition of Calvin cycle activity.

In conclusions $\mathrm{B}$ can induce an alteration in the mesophyll cells that, in turn, reduces electron transport rate and light utilization. On the other hand, the reduced activity of some enzymes involved in $\mathrm{CO}_{2}$ assimilation (ribulose-1,5-bisphosphate carboxylase/oxygenase and fructose-1,6-bisphosphate phosphatase; Han et al., 2009) also determines a reduction in NADPH and ATP utilization, thus inhibiting in electron transport rate. Consequently, the reduction in electron transport rate determines an oxidative stress that generates ROS in the chloroplast. These ROS oxidized organic molecules as chlorophyll and lipid and, probably, induce cell death. The consequence of these events is the visible symptoms of damage which are typically located at the leaf margin where $B$ is accumulated to a large extent (Guidi et al., 2011).

\section{CONCLUSION}

Boron is a nutrient element that is involved in different plant processes such as cell division, cell wall synthesis, sugars translocation, protein synthesis and membrane functions. In general, B excess affects leaf tips and edges disorders. It is frequently contained at excessive concentration in both soil and irrigation water and it may induce several metabolic disorders (decreases in chlorophyll content, inhibition of photosynthesis, structural damage to thylakoids, deposition of lignin or suberin, peroxidation of lipids and altered activities of antioxidant pathways) and reduce plant growth.

Plants are frequently subjected to concomitant B toxicity and salinity because of plants are irrigated with water containing high level of B and salts or plants are grown in soils with high content of salts and $\mathrm{B}$. It has been reported that the combination of high $\mathrm{B}$ levels and salinity induced less toxic effects on plant growth than would be expected probably because of reduced uptake of $\mathrm{B}$ in the presence of chloride and reduced uptake of chloride in the presence of B (Yermiyahu et al., 2008). On the other hand, in the simultaneous presence of B and salts, boric acid influences the activity of membrane components which regulate the functions of aquaporin isoforms and ATPase increasing the tolerance to salts stress (Martinez-Ballesta et al., 2008). Boron was assimilated from soils by root and then transported via xylem or phloem to the leaves with differences in relation to leaf age. Xylem translocation is mainly directed to the mature leaves while phloem translocation supplies the major proportion of nutrient requirements for actively growing areas, such as young leaves, fruits and seeds. Plant species show different sensitivity to B toxicity. Boron tolerance is likely associated with the ability to exclude B at root level: a reduced permeability of membrane lipids and/or the presence of carriers (BOR and NIP) essential for boron extrusion from the cytoplasm may be responsible for reduced $\mathrm{B}$ accumulation.

Although the physiological and biochemical mechanisms on the basis of B toxicity is not complete clear, certainly this element at high concentration induces: (i) alteration of cell wall structure; (ii) alterations of biochemical pathways binding to the ribose moieties of important molecules such as ATP and reduced form of $\mathrm{NAD}(\mathrm{P}) \mathrm{H}$; (iii) alterations of cell division and development by binding to ribose within RNA (Reid et al., 2004).

Plants species show different sensitivity to B toxicity being the tolerance related to a lower uptake (or a major efflux) of $\mathrm{B}$ into both roots and shoots. It has been reported as BOR1 is an efflux-type borate transporters essential to transport B from root to shoots, is degraded 
in the presence of toxic levels of B. In addition to, another boron efflux-type transporter, BOR4 is related to the tolerance to B.

As in most ionic stresses, toxic levels of B cause the formation of ROS. In order to avoid the harmful effects of these reactive molecules, plants have evolved an effective scavenging system composed of antioxidant molecules and antioxidant enzymes such as SOD, CAT, APX and GR. In addition to, organic antioxidant compounds (e.g., phenols, AsA, GSH or anthocyanins) could enhance the reaction to these toxic reactive molecules. It has well known that B toxicity trigged ROS production and, in the same way, a general stimulation of enzymatic and nonenzymatic antioxidant systems was reported.

In conclusion, because of the relative little few information on different aspects of B toxicity, further researches are necessary in order to asses: (i) the biochemical or physiological target of the B toxicity; (ii) the identification of the carriers involved in B uptake and translocation and (iii) the contribute of antioxidants in scavenging of ROS induced by B and their involvement in B tolerance.

\section{ACKNOWLEDGMENT}

This study was funded by MIUR-PRIN 2009 (Ministero dell'Istruzione, dell'Universita e della Ricerca, Italy, Project "Physiological response of vegetables crops to boron excess").

\section{REFERENCES}

Agati, G. and M. Tattini, 2010. Multiple functional roles of flavonoids in photoprotection. New Phytol., 186: 786-793. DOI: $10.1111 /$ j.1469-8137.2010.03269.x

Alpaslan, M. and A. Gunes, 2001. Interactive effects of boron and salinity stress on the growth, membrane permeability and mineral composition of tomato and cucumber plants. Plant Soil, 236: 123-128. DOI: 10.1023/A:1011931831273

Alscher, RG., 1989. Biosynthesis and antioxidant function of glutamylcysteine synthetase in tomato cells selected for glutathione in plants. Physiol. Plant, 77: 457-464. DOI: 10.1111/j.13993054.1989.tb05667

Ardic, M., A.H. Sekmen, S. Tokur, F. Ozdemir and I. Turkan, 2009. Antioxidant response of chickpea plants subjected to boron toxicity. Plant Biol., 11: 328-338. PMID: 19470104

Arora, A., T.M. Byrem, M.G. Nair and G.M. Strasburg, 2000. Modulation of liposomal membrane fluidity by flavonoids and isoflavonoids. Arch. Biochem. Biophys., 373: $102-109 . \quad$ DOI: 10.1006/abbi.1999.1525
Asensi-Fabado, M.A. and S. Munne-Bosch, 2011. Vitamins in plants: occurrence, biosynthesis and antioxidant fucntion. Trends Plant Sci., 15: 582-592. PMID: 20729129

Azevedo-Neto, A.D., J.T. Prisco, J. Eneas-Filho, C.E. Braga de Abreu Eneas and E. Gomes-Filho, 2006. Effect of salt stress on antioxidative enzymes and lipid peroxidation in leaves and roots of salt-tolerant and salt-sensitive maize genotypes. Environ. Exp. Bot., 56: 87-94. DOI: 10.1016/j.envexpbot.2005.01.008

Bahler, B.D., K.L. Steffen and M.D. Orzolek, 1991. Morphological and biochemical comparison of a purple-leafed and a green-leafed pepper cultivar. Hort Sci., 26: 736-736.

Ben-Gal, A. and U. Shani, 2002. Yield, transpiration and growth of tomatoes under combined excess boron and salinity stress. Plant Soil, 247: 211-221. DOI: 10.1023/A:1021556808595

Bohnert, H.J. and R.G. Jensen, 1996. Strategies for engineering water-stress tolerance in plants. Trends Biotechnol., 14: 89-97. DOI: 10.1016/01677799(96)80929-2

Bolaños, L., K., Lukaszewski, I. Bonilla, B. Dale, 2004. Why boron? Plant Physiol. Biochem., 42: 907-912. PMID: 15694285

Bonilla, I., A. E M 1-Hamdaoui and L. Bolaños, 2004. Boron and calcium increase Pisum sativum seed germination and seedling development under salt stress. Plant Soil, 267: 97-107. DOI: 10.1007/s11104-005-4689-7

Bowler, C., M.V. Montagu and D. Inze, 1992. Superoxide dismutase and stress tolerance. Ann. Rev. Plant Physiol. Plant Mol. Biol., 43: 83-116. DOI: 10.1146/annurev.pp.43.060192.000503

Brown, P.H and H. Hu, 1996. Phloem mobility of boron is species dependent: Evidence for phloem mobility in sorbitol-rich species. Ann. Bot., 77: 497-506. DOI: 10.1006/anbo.1996.0060

Brown, P.H. and B.J. Shelp, 1997. Boron mobility in plants. Plant Soil, 193: 85-101. DOI: 10.1023/A:1004211925160

Brown, P.H., N. Bellalou, H. Hu and A. Dandekar, 1999. Transgenically enhanced sorbitol synthesis facilitates phloem boron transport and increases tolerance of tobacco to boron deficiency. Plant Physiol., 119: 17-20.

Buettner, G.R., 1993. The pecking order of free radicals and antioxidants: lipid peroxidation, $\alpha$-tocopherol and ascorbate. Arch. Biochem. Biophys., 300: 535543. PMID: 8434935 
Cakmak, I. and V. Romheld, 1997. Boron deficiencyinduced impairments of cellular fractions in plants. Plant Soil, 193: 71-83.

Cervilla, L.M., B. Blasco, J.J. Rìos, L. Romero and J.M. Ruiz, 2007. Oxidative stress and antioxidants in tomato (Solanum lycopersicum) plants subjected to boron toxicity. Ann. Bot., 100: 747-756. DOI: 10.1093/aob/mcm 156

Cervilla, L.M., B. Blasco, J.J. Rios, M.A., Rosales and E. Sanchez-Rodriguez et al., 2012. Parameters symptomatic for boron toxicity in leaves of tomato plants. J. Bot., 2012: 1-17. DOI: $10.1155 / 2012 / 726206$

Chalker-Scott, L., 1999. Environmental significance of anthocyanins in plant stress responses. Photochem. Photobiol., 70: 1-9. DOI: 10.1111/j.17511097.1999.tb01944.x

Chalker-Scott, L., 2002. Do anthocyanins function as osmoregulators in leaf tissues? Adv. Bot. Res., 37: 103-106. DOI: 10.1016/S0065-2296(02)37046-0

Chamacho-Cristobal, J.J., D. Anzellotti and A. Gonzàlez-Fontez, 2002. Changes in phenolic metabolism of tobacco plants during short-term boron deficiency. Plant Physiol. Biochem., 40: 9971002. DOI: 10.1016/S0981-9428(02)01463-8

Chamacho-Cristobal, J.J., J. Rexach, A. GonzàlezFontez, 2008. Boron in plants: deficiency and toxicity. J. Integr. Plant Biol., 50: 1247-1255. DOI: 10.1111/j.1744-7909.2008.00742.x

Chen, L.S. Han S., Y.P. Qi and L.T. Yang, 2012. Boron stresses and tolerance in citrus Afr. J. Biotechnol., 11: 5961-5969.

Crozier, A., T. Yokota, I.B. Jaganath, S.C. Marks, M. Saltmarsh and M.N. Clifford, 2006. Secondary metabolites in fruits, vegetables, beverages and other plant based dietary components. In: Plant Secondary Metabolites: Occurrence, Structure and Role in the Human Diet, Crozier, A., M.N. Clifford and H. Ashihara, (Eds.). Blackwell, Oxford, ISBN: 1-4051-2559-8, pp: 208-302.

Dangles, O., 2012. Antioxidant activity of plant phenols: chemical mechanisms and biological significance. Curr. Org. Chem., 16: 692-714.

Dannel, F., H. Pfeffer and V. Romheld, 2000. Characterization of root boron $p$ Characterization of root boron pools, boron uptake and boron translocation in sunflower using the stable isotopes ${ }^{10} \mathrm{~B}$ and ${ }^{11} \mathrm{~B}$. Aust. J. Plant Physiol., 27: 397-405.

Dhindsa, R.S. and W. Matowe, 1981. Drought tolerance in two mosses: Correlated with enzymatic defence against lipid peroxidation. J. Exp. Bot., 32: 79-91. DOI: $10.1093 / \mathrm{jxb} / 32.1 .79$
Dordas, C. and P.H. Brown, 2001. Evidence for channel mediated transport of boric acid in squash (Cucurbita pepo). Plant Soil, 235: 95-103. DOI: 10.1023/A:1011837903688

Dordas, C., M.S. Chrispeels and P.H. Brown, 2000. Permeability and channel-mediated transport of boric acid across membrane vesicles isolated from squash roots. Plant Physiol., 124: 1349-1362. PMID: 11080310

Edelstein, M., M. Ben-Hur, R. Cohen, Y. Burger and I. Ravina, 2005. Boron and salinity effects on grafted and non-grafted melon plants. Plant Soil, 269: 273284. DOI: $10.1007 / \mathrm{s} 11104-004-0598-4$

EFSA, 2004. Opinion of the scientific panel on dietetic products, nutrition and allergies on a request from the commission related to the tolerable upper intake level of boron (sodium borate and boric acid). EFSA J. 80: 1-22.

El-Hhamdaoui, A., M. Redondo-Nieto, R. Rivilla, I. Bonilla and L. Bolaños, 2003. Effects of boron and calcium nutrition on the establishment of the Rhizobium leguminosarum-pea (Pisum sativum) symbiosis and nodule development under salt stress. Plant Cell Environ., 26: 1003-1011. DOI: 10.1046/j.1365-3040.2003.00995.x

EPA, 1996. The integrated risk information system (IRIS). National Center for Environmental Asaessment, Washington, DC.

Eraslan, F., A. Inal, A. Gunes and M. Alpaslan, 2007a. Impact of exogenous salicylic acid on the growth, antioxidant activity and physiology of carrot plants subjected to combined salinity and boron toxicity. Scientia Hortic., 113: 120-128. DOI: 10.1016/j.scienta.2007.03.012

Eraslan, F., A. Inal, D.J. Pilbeam and A. Gunes, 2008. Interactive effects of salicylic acid and silicon on oxidative damage and antioxidant activity in spinach (Spinacia oleracea L. CV. Matador) grown under boron toxicity and salinity. Plant Growth Reg., 55: 207-219. DOI: 10.1007/s10725-008-9277-4

Eraslan, F., A. Inal, O. Savastur and A. Gunes, $2007 \mathrm{~b}$. Changes in antioxidative system and membrane damage of lettuce in response to salinity and boron toxicity. Scientia Hortic., 114: 5-10. DOI: 10.1016/j.scienta.2007.05.002

Ferreres, F., R. Figueiredo, S. Bettencourt, I. Carqueijeiro and J. Oliveira et al., 2011. Identification of phenolic compounds in isolated vacuoles of the medicinal plant Catharanthus roseus and their interaction with vacuolar class III peroxidase: an $\mathrm{H}_{2} \mathrm{O}_{2}$ affair? J. Exp. Bot., 62: 28412854. DOI: $10.1093 / \mathrm{jxb} / \mathrm{erq} 458$ 
Foyer, C.H. and G. Noctor, 2011. Ascorbate and glutathione: The heart of the redox hub ${ }^{1}$. Plant Physiol., 155: 2-18. DOI: 10.1104/pp.110.167569

Foyer, C.H. and M.A. Lelandais, 1996. A comparison of the relative rates of transport of ascorbate and glucose across the thylakoid, chloroplast and plasmalemma membranes of pea leaves mesophyll cells. J. Plant Physiol., 148: 391-398. DOI: 10.1016/S0176-1617(96)80271-9

Fryer, M.J., 1992. The antioxidant effects of thylakoid vitamin E ( $\alpha$-tocopherol). Plant Cell Environ., 15: 381-392. DOI: 10.1111/j.1365-3040.1992.tb00988.x

Garcia, P.O.C., R.M. Rivero, L.R. Lopez-Lefebre, E. Sanchez and J.M. Ruiz et al., 2001. Response of oxidative metabolism to the application of carbendazim plus boron in tobacco. Aust. J. Plant. Physiol., 28: 801-806. DOI: 10.1071/PP00098

Goldbach, H.E., Q. Yu., R. Wingender., M. Schulz and M. Wimmer et al., 2001. Rapid response reactions of roots to boron deprivation. J. Plant Nut. Soil Sci., 161: 173-181. DOI: 10.1002/15222624(200104)164:2<173::AID-JPLN173>3.0.CO;2-F

Gould, K.S., J. McKelvie and K.R. Markham, 2002. Do anthocyanins function as antioxidants in leaves? Imaging of $\mathrm{H}_{2} \mathrm{O}_{2}$ in red and green leaves after mechanical injury. Plant Cell Environ., 25: 12611269. DOI: $10.1046 / j .1365-3040.2002 .00905 . x$

Gould, K.S., K.R. Markham, R.H. Smith and J.J. Goris, 2000. Functional role of anthocyanins in the leaves of Quintinia serrata A. Cunn. J. Exp. Bot., 51: 1107-1115. DOI: 10.1093/jexbot/51.347.1107

Grace, S.C. and B.A. Logan, 2000. Energy dissipation and radical scavenging by the plant phenylpropanoid pathway. Philos. Trans. Royal Soc. London, 355: 1499-1510.

Guidi, L., E. Degl'Innocenti, G. Carmassi, D. Massa and A. Pardossi, 2011. Effects of boron on leaf chlorophyll fluorescence of greenhouse tomato grown with saline water. Environ. Exp. Bot., 73: 5763. DOI: 10.1016/j.envexpbot.2010.09.017

Gunes, A., G. Soylemezoglu, A. Inal, E.G. Bagci and S. Coban et al., 2006. Antioxidant and stomatal responses of grapevine (Vitis vinifera L.) to boron toxicity. Scientia Hortic., 110: 279-284. DOI: 10.1016/j.scienta.2006.07.014

Gupta, U.C., Y.W. Jame, C.A. Campbell, A.J. Leyshon and W. Nicholaichuck, 1985. Boron toxicity and deficiency: A review. Can. J. Soil Sci., 65: 381-409. DOI: $10.4141 /$ cjss85-044

Han, S., L.S. Chen, H.X. Jiang, B.R. Smith, L.T. Yang and C.Y. Xie, 2008. Boron deficiency decreases growth and photosynthesis and increases starch and hexoses in leaves of citrus seedlings. J. Plant Physiol., 165: 1331-1341. PMID: 18191499
Han, S., N. Tang, H-X. Jiang, L.T. Yang and Y. Lee et al., 2009. $\mathrm{CO}_{2}$ assimilation, photosystem II photochemistry, carbohydrate metabolism and antioxidant system of citrus leaves in response to boron stress. Plant Sci., 176: 143-153. DOI: 10.1016/j.plantsci.2008.10.004

Havaux, M. and R. Lannoye, 1985. Drought resistance of hard wheat cultivars measured by a rapid chlorophyll fluorescence test. J. Agric. Sci., 104: 501-504. DOI: 10.1017/S0021859600044257

Health Canada, 2006. Compliance Policy for Natural.

Herms, D.A. and W.J. Mattson, 1992. The dilemma of plants: to grow or defend. Quart. Rev. Biol., 67: 283-335.

Hernandez, I., L. Alegre, F. Van Breusegem and S. Munne-Bosch, 2009. How relevant are flavonoids as antioxidants in plants? Trends Plant Sci., 14: 125132. PMID: 19230744

Holton, T.A. and E.C. Cornish, 1995. Genetics and biochemistry of anthocyanin biosynthesis. Plant Cell, 7: 1071-1083. PMID: 12242398

HSDB, 2003. Boron. Division of Specialized Information Services, National Library of Medicine.

Hu, H., S.G. Penn C.B. Lebrilla and P.H. Brown, 1997. Isolation and characterization of soluble B-complexes in higher plants. Plant Physiol., 113: 649-655.

Ishikawa, M., T. Kiba and N.H. Chua, 2006. The Arabidopsis SPA1 gene is required for circadian clock function and photoperiodic flowering. Plant J., 46: 736-746. PMID: 16709190

Javanmardi, J., A. Khalighi, A. Kashi, H.P. Bais and J.M. Vivanio, 2002. Chemical characterization of basil (Ocimum basilicum L.) found in local accessions and used in traditional medicines in Iran. J. Agric. Food Chem., 50: 5878-5883. PMID: 12358453

Jimenez, A., J.A. Hernandez, G. Pastori, L.A. Del Rio, F. Sevilla, 1998. Role of the ascorbate-glutathione cycle of mitochondria and peroxisomes in the senescence of pea leaves. Plant Physiol., 118: 13271335. DOI: $10.1104 /$ pp.118.4.1327

Kagan, V.E., J.P. Fabisiak and P.J. Quinn, 2000. Coenzyme $\mathrm{Q}$ and vitamin $\mathrm{E}$ need each other as antioxidants. Protoplasma, 214: 11-18. DOI: 10.1007/BF02524257

Kamali, A.R. and N.F. Childers, 1967. Effect of boron nutrition on peach anatomy. J. Am. Soc. Hortic. Sci., 90: 33-46.

Karabal, E., M. Yucel and H.A. Oktem, 2003. Antioxidant responses of tolerant and sensitive barley cultivars to boron toxicity. Plant Sci., 164: 925-933. DOI: 10.1016/S0168-9452(03)00067-0 
Kaya, C., A. Levent Tuna, M. Dikilitas, M. Ashraf and S. Koskeroglu et al., 2009. Supplementary phosphorus can alleviate boron toxicity in tomato. Scientia Hortic., 121: 284-288. DOI: 10.1016/j.scienta.2009.02.011

Keles, Y., I. Oncel, N. Yenice, 2004. Relationship between boron content and antioxidant compounds in citrus leaves taken from fields with different water source. Plant Soil, 265: 345-353. DOI: 10.1007/s 11104-005-0646-8

Kohl, H.C. and J.J. Oertli, 1961. Distribution of boron in leaves. Plant Physiol., 36: 420-424.

Kot, F.S., 2009. Boron sources, speciation and its potential impact on health. Rev. Environ. Sci. Biotechnol., 8: 3-28. DOI: 10.1007/s11157-0089140-0

Kramer, D.M., G. Johnson, O. Kiirats and G.E. Edwards, 2004. New fluorescence parameters for the determination of QA redox state and excitation energy fluxes. Res., 79: 209-218. DOI: 10.1023/B:PRES.0000015391.99477.0d

Larson, R.A., 1988. The antioxidants of higher plants. Phytochemistry, 27: 969-978. DOI: 10.1016/00319422(88)80254-1

Larsson, E.H., J.F. Bornman and H. Asp, 1998. Influence of UV-B radiation and $\mathrm{Cd}^{2+}$ on chlorophyll fluorescence, growth and nutrient content in Brassica napus. J. Exp. Bot., 49: 1031-1039. DOI: 10.1093/jxb/49.323.1031

Lee, J. and C.F. Scagel, 2009. Chicoric acid found in basil (Ocimum basilicum L.) leaves. Food Chem., 115: 650-656. DOI: 10.1016/j.foodchem.2008.12.075

Lee, S.K.D., 2006. Hot pepper response to interactive effects of salinity and boron. Plant Soil Environ., 52: 227-233.

Lenoble, M.E., Blevins D.G. and Miles R.J., 1996. Prevention of aluminium toxicity with supplemental boron. II. Stimulation of root growth in an acidic, high-aluminium subsoil. Plant Cell Environ., 19: 1143-1148. DOI: $\quad 10.1111 / \mathrm{j} .1365-$ 3040.1996.tb00429.x

Loomis, W.D. and R.W. Durst, 1992. Chemistry and biology of boron. Biofactors, 3: 229-239. PMID: 1605832

Lopez-Gomez, E., M.A. San Juan, P. Diaz-Vivancos, J. Mataix Beneyto and M.F. Garcia-Legaz et al., 2007. Effect of rootstocks grafting and boron on the antioxidant systems and salinity tolerance of loquat plants (Eriobotrya japonica Lindl). Environ. Exp. Bot., 60: 151-158. DOI: 10.1016/j.envexpbot.2006.10.007
Lovatt, C.J. and L.M. Bates. 1984. Early effects of excess boron on photosynthesis and growth of Curubita pepo. J. Expt. Bot., 5: 297-305. DOI: $10.1093 / \mathrm{jxb} / 35.3 .297$

Marschner, H., I. Cakmak and H. Kurz, 1995. Short-term effects of boron, germanium and high light intensity on membrane permeability in boron deficient leaves of sunflower. Physiol. Plant., 95: 11-18. DOI: 10.1111/j.1399-3054.1995.tb00801.x

Martinez-Ballesta, M.C., E. Bastia, C. Zhu, A.R. Schaffner and B. Gonzalez-Moro et al., 2008. Boric acid and salinity effects on maize roots. Response of aquaporins ZmPIP1 and ZmPIP2 and plasma membrane $\mathrm{H}^{+}$-ATPase, in relation to water and nutrient uptake. Physiol. Plant., 132: 479-490. PMID: 18334001

May, M.J., T. Vernoux, C. Leaver, M.V. Montagu and D. Inze, 1998. Glutathione homeostasis in plants: implications for environmental sensing and plant development. J. Exp. Bot., 49: 649-667. DOI: $10.1093 / \mathrm{jxb} / 49.321 .649$

Melgar, J.C., L. Guidi, D. Remorini, G. Agati and E. Degl'Innocenti et al., 2009. Antioxidant defenses and oxidative damage in salt-treated olive plants under contrasting sunlight irradiance. Tree Physiol., 29: 1187-1198. DOI: 10.1093/treephys/tpp047

Mittler, R., 2002. Oxidative stress, antioxidants and stress tolerance. Trends Plant Sci., 7: 405-410. PMID: 12234732

Miwa, K., J. Takano, H. Omori, M. Seki and K. Shinozaki et al., 2007. Plants tolerant of high boron levels. Science, 318: 1417-1417. DOI: 10.1126/science. 1146634

Molassiotis, A., T. Sotiropoulos, G. Tanou, G. Diamantidis and I. Therios, 2006. Boron induced oxidative damage and antioxidant and nucleolytic responses in shoot tips culture of the apple rootstock EM9 (Malus $x$ domestica Borkh). Environ. Exp. Bot., 56: 54-62. DOI: 10.1016/j.envexpbot.2005.01.002

Mondy, N.I. and C.B. Munshi, 1993. Effect of boron on enzymatic discoloration and phenolic and ascorbic acid contents of potatoes. J. Agric. Food Chem., 41: 554-556. DOI: 10.1021/jf00028a009

Moore, J.W., 1991. Inorganic Contaminants of Surface Water: Research and Monitoring Priorities. 1st Edn., Springer-Verlag, New York, NY, ISBN-10: 0387972811 , pp: 334.

Mullen, W., S.C. Marks and A. Crozier, 2007. Evaluation of phenolic compounds in commercial fruit juices and fruit drinks. J. Agric. Food Chem., 55: 3148-3157. PMID: 17362029 
Nable, R.O., G.S. Bañuelos and J.G. Paull. 1997. Boron toxicity. Plant Soil. 193: 181-198.

Nable, R.O., R.C.M. Lance and B. Cartwright, 1990. Uptake of boron and silicon by barley genotypes with differing susceptibilities to boron toxicity. Ann. Bot. 66: 83-90.

Noctor, G. and C. Foyer, 1998. Ascorbate and glutathione: keeping active oxygen under control. Annu. Rev. Plant Physiol. Plant Mol. Biol., 49: 249279. PMID: 15012235

Noctor, G., A.C.M. Arisi, L. Jouanin, K.J. Kunert and H. Rennenberg et al., 1998. Glutathione: biosynthesis, metabolism and relationship to stress tolerance explored in transformed plants. J. Exp. Bot., 49: 623-647. DOI: $10.1093 / \mathrm{jxb} / 49.321 .623$

Noguchi, K., T. Ishii, T. Matsunaga, K. Kakegawa and H. Hayashi et al., 2003. Biochemical properties of the cell wall in the Arabidopsis mutant bor1-1 in relation to boron nutrition. J. Plant Nutr. Soil Sci., 166: 175-178. DOI: 10.1002/jpln.200390025

Nozawa, A., J. Takano, M. Kobayashi, N. Wiren and T. Fujiwara, 2006. Roles of BOR1, DUR3 and FPS1 in boron transport and tolerance in Saccharomyces cerevisiae. FEMS Microbiol. Lett., 262: 216-222. PMID: 16923078

O'Neill, M.A., T. Ishii, P. Albersheim and A.G. Darvill, 2004. Rhamnogalacturonan II: structure and function of a borate cross-linked cell wall pectic polysaccharide. Ann. Rev. Plant Biol., 55: 109-139. DOI: 10.1146/annurev.arplant.55.031903.141750

Papadakis, I., K.N. Dimassi, A.M. Bosabalidis, I.N. Therios and A. Patakas et al., 2004b. Effects of B excess on some physiological and anatomical parameters of 'Navelina' orange plants grafted on two rootstocks. Env. Exp. Bot., 51:247-257. DOI: 10.1016/j.envexpbot.2003.11.004

Papadakis, I.E., N. Dimassi, A.M. Bosabalidis, I.N. Therios, A. Patakas and A. Giannakoula, 2004a. Boron toxicity in 'Clementine' mandarin plants grafted on two rootstocks. Plant Sci., 166, 539-547. DOI: 10.1016/j.plantsci.2003.10.027

Pate, J.S., 1975. Exchange of solutes between phloem and xylem and circulation in the whole plant. In: Transport in Plants, Zimmermann M.H., Milburn J.A. (Eds.), Springer-Verlag, New York, ISBN-10: 3540073140, pp: 451-473.

Pereira, W.E, D.L. de Siqueira, C.A. Martínez and M. Puiatti, 2000. Gas exchange and chlorophyll fluorescence in four citrus rootstocks under aluminum stress. J. Plant Physiol., 157: 513-520. DOI: $10.1016 / \mathrm{S} 0176-1617(00) 80106-6$
Pourcel, L., J.M. Routaboul, V. Cheynier, L. Lepiniec and I. Debeaujon, 2006. Flavonoid oxidation in plants: from biochemical properties to physiological functions. Trends Plant Sci., 12: 29-36. PMID: 17161643

Reid, R.J., 2007. Identification of boron transporter genes likely to be responsible for tolerance to boron toxicity in wheat and barley. Plant Cell Physiol., 48: 1673-1678. DOI: 10.1093/pcp/pcm 159

Reid, R.J., J.E. Hayes, A. Post, J.C.R. Stangoulis and R.D. Graham, 2004. A critical analysis of the causes of boron toxicity in plants. Plant Cell Environ., 27: 1405-1414. DOI: $\quad 10.1111 /$ j.13653040.2004.01243.x

Rowe, R.I. and C.D. Eckhert, 1999. Boron is required for zebrafish embryogenesis. J. Exp. Biol., 202: 16491654. PMID: 10333510

Rozema, J., J. Van de Staaij, L.O. Bjorn and M. Caldwell, 1997. UV-B as an environmental factor in plant life: stress and regulation. Trends Ecol. Evol., 12: 22-28. PMID: 21237957

Ruiz, J.M., G. Bretones, M. Baghour, A. Belakbir and L. Romero, 1998. Relationship between boron and phenolic metabolism in tobacco leaves. Phytochem., 48: 269-272. DOI: 10.1016/S0031-9422(97)01132-1

Ruiz, J.M., R.M. Rivero and L. Romero, 2003. Preliminary studies on the involvement of biosynthesis of cysteine and glutathione in the resistance to boron toxicity in sunflower plants. Plant Sci., 165: 811-817. DOI: 10.1016/S01689452(03)00276-0

Ruiz, J.M., R.M. Rivero and L. Romero, 2006. Boron increases synthesis of glutathione in sunflower plants subjected to aluminium stress. Plant Soil, 279: 25-30. DOI: 10.1007/s11104-005-7931-4

Ryang, S.Z., S.Y. Woo, S.Y. Know, S.H. Kim and S.H. Lee et al., 2009. Changes of net photosynthesis, antioxidant enzyme activities and antioxidant contents of Liriodendron tulipifera under elevated ozone. Photosynthetica, 47: 19-25. DOI: 10.1007/s11099-009-0005-8

Sanchez-Fernandez, R., M. Fricker., L.B. Corben, N.S. White and N. Sheard et al., 1997. Cell proliferation and hair tip growth in the Arabidopsis root are under mechanistically different forms of redox control. P. Natl. Acad. Sci. USA, 94: 2745-50.

SanPiN, 2001. Sanitary requirements of safety and food value of foodstuffs. Moscow: Minzdrav RF.

Shan, B., Y.Z. Cai, M. Sun and H. Corke, 2005. Antioxidant capacity of 26 spice extracts and characterization of their phenolic constituents. J. Agric. Food Chem., 53: 7749-7759. PMID: 16190627 
Shao, H.B., L.Y. Chu, Z.H. Lu and C.M Kang, 2008. Primary antioxidant free radical scavenging and redox signaling pathways in higher plant cells. Int. J. Biol. Sci., 4: 8-14.

Shelp, B.J., 1987. The composition of phloem exudate and xylem sap from broccoli (Brassica oleracea var. italica) supplied with $\mathrm{NH}_{4}^{+}, \mathrm{NO}_{3}^{-}$or $\mathrm{NH}_{4} \mathrm{NO}_{3}$. J. Exp. Bot., 38: 1619-1636. DOI: $10.1093 / \mathrm{j} \times b / 38.10 .1619$

Shelp, B.J., 1988. Boron mobility and nutrition in broccoli (Brassica oleracea var. Italica). Ann., Bot. 61: 83-91.

Sheng, O., G.F. Zhou, Q.J. Wei, S.A. Peng and X.X. Deng, 2010. Effects of excess boron on growth, gas exchange and boron status of four orange scionrootstock combinations. J. Plant Nutr. Soil Sci., 173: 469-476. DOI: 10.1002/jpln.200800273

Sheng, O., S.W. Song, S.A. Peng and X.X. Deng, 2009. The effects of low boron on growth, gas exchange, boron concentration and distribution of 'Newhall' navel orange (Citrus sinensis Osb.) plants grafted on two rootstocks. Sci. Hort., 121: 278-283. DOI: 10.1016/j.scienta.2009.02.009

Sherwin, H.W. and J.M. Farrant, 1998. Protection mechanisms against excess light in the resurrection plants Craterostigma wilmsii and Xerophyta viscosa. Plant Growth Reg., 24: 203-210. DOI: 10.1023/A:1005801610891

Shomron, N. and G. Ast, 2003. Boric acid reversibly inhibits the second step of pre-mRNA splicing. FEBS lett., 552: 219-224.

Singh, D.P., J. Belay, J.K. Mclnerney and L. Day, 2012. Impact of boron, calcium and genetic factors on vitamin $\mathrm{C}$, carotenoids, phenolic acids, anthocyanins and antioxidant capacity of carrots (Daucus carota). Food Chem., 132: 1161-1170.

Smirnoff, N., 2000. Ascorbic acid: metabolism and functions of a multifacetted molecule. Curr. Opin. Plant Biol., 3: 229-235.

Smirnoff, N., P.L. Conklin and F.A Loewus, 2001. Biosynthesis of ascorbic acid in plants: a renaissance. Ann. Rev. Plant Biol., 52: 437-467. DOI: 10.1146/annurev.arplant.52.1.437

Sotiropoulos, T.E., A. Molassiotis, D. Almaliotis, G. Mouhtaridou and K. Dimassi et al., 2006. Growth, nutritional status, chlorophyll content and antioxidant responses of the apple rootstock $M M$ 111 shoots cultured under high boron concentrations in vitro. J. Plant Nutr., 29: 575-583.

Sotiropoulos, T.E., N.I. Therios, N.K. Dimassi, A. Bosbalidis and G. Kofilids. 2002. Nutritional status, growth, $\mathrm{CO}_{2}$ assimilation and leaf anatomical responses in two kiwi fruit species under boron toxicity. J. Plant Nutr., 25: 1244-1261.
Soylemezoglu, G., K. Demir, A. Inal and A. Gunes, 2009. Effect of silicon on antioxidant and stomatal response of two grapevine (Vitis vinifera L.) rootstocks grown in boron toxic, saline and boron toxic-saline soil. Scientia Hortic., 123: 240-246. DOI: $10.1016 / \mathrm{j}$. scienta.2009.09.005

Stangoulis, J.C.R, P.H. Brown, N. Bellaloui, R.J. Reid and R.D. Graham, 2001. The efficiency of boron utilization in canola. Aust. J. Plant Physiol., 28: 1109-1114.

Surveswaran, S., Y.Z. Cai, H. Corke and M. Sun, 2007. Systematic evaluation of natural phenolic antioxidants from 133 Indian medicinal plants. Food Chem., 102: 938-953. DOI: 10.1016/j.foodchem.2006.06.033

Sutton, T., U. Baumann, J. Hayes, N.C. Collins and B.J. Shi et al., 2007. Boron-toxicity tolerance in barley arising from efflux transporter amplification. Science., 318: 1446-1449. DOI: 10.1126/science. 1146853

Takahama, U. and T. Oniki, 1997. A peroxide/phenolics/ascorbate system can scavenge hydrogen peroxide in plant cells. Physiol. Plant., 101: 845-852. DOI: 10.1111/j.13993054.1997.tb01072.x

Takano, J., K. Miwa, L.X. Yuan, N. von Wirèn and T. Fujiwara, 2005. Endocytosis and degradation of BOR1, a boron transporter of Arabidopsis thaliana, regulated by boron availability. Proc. Natl. Acad. Sci. USA, 102: 12276-12281. DOI: 10.1073/pnas.0502060102

Takano, J., K. Noguchi, M. Yasumori, M. Kobayashi and Z. Gajdos, 2002. Arabidopsis boron transporter for xylem loading. Nature, 420: 337-340. DOI:10.1038/nature01139

Takano, J., M. Wada, U. Ludewig, G. Schaaf, N. Von Wirèn and T. Fujiwara, 2006. The Arabidopsis major intrinsic protein NIP5;1 is essential for efficient boron uptake and plant development under boron limitation. Plant Cell, 18: 1498-1509. PMID: 16679457

Takano, J., M. Yamagami, K. Noguchi, H. Hayashi and T. Fujiwara, 2001. Preferential translocation of boron to young leaves in Arabidopsis thaliana regulated by the BOR1 gene. Soil Sci. Plant Nutr., 47: $345-357 . \quad$ DOI: 10.1080/00380768.2001.10408398

Tanaka, M. and T. Fujiwara, 2008. Physiological roles and transport mechanisms of boron: perspectives from plants. Pflugers. Arch., 456: 671-677. PMID: 17965876

Thomas, C.E., L.R. McLean, R..A Parker and D.F. Ohlweiler, 1992. Ascorbate and phenolic antioxidant interactions in prevention of liposomal oxidation. Lipids, 27: 543-550. PMID: 1453885 
Tsuda, T., K. Shiga, K. Ohshima, S. Kawakishi and T. Osawa, 1996. Inhibition of lipid peroxidation and the active oxygen radical scavenging effect of anthocyanin pigments isolated from Phaseolus vulgaris L. Biochem. Pharmacol., 52: 1033-1039. PMID: 8831722

USGS, 2009. Mineral Commodity Summaries. 1st Edn., Government Printing Office, USA., ISBN-10; 1411322959, pp: 198.

Velez-Ramirez, A.I., W. van Ieperen, D. Vreugdenhil and F.F. Millenaar, 2011. Plants under continous light. Trends Plant Sci, 16: 310-318. DOI: 10.1016/j.tplants.2011.02.003

Wang, J.Z., S.T. Tao, K.J. Qi, J. Wu and H.Q. Wu et al., 2011. Changes in photosynthetic properties and antioxidative system of pear leaves to boron toxicity. Afr. J. Biotecnol., 10: 19693-19700. DOI: 10.5897/AJB11.557

Warington, K., 1923. The Effect of Boric Acid and Borax on the Broad Bean and certain other Plants. Ann. Bot., 37: 629-672.

Weinthal, E. P., Y. Vengosh, A. Muti and W. Kloppmann, 2005. The EU drinking water directive: the boron standard and scientific uncertainty. Eur Env, 15:1-12. DOI: 10.1002/eet.369

WHO, 1998. Environmental Health Criteria. World Health Organization, Geneva, Switzerland, ISBN10: 9241572043, pp: 201.

Wingate, V.P.M, M.A. Lawton, C.J. Lamb, 1988. Glutathione causes a massive and selective induction of plant defense genes. Plant Physiol., 87: 206-210. DOI: $10.1104 /$ pp.87.1.206
Wise, R.R. and A.W. Naylor, 1987. Chilling-enhanced photooxidation: Evidence for the role of singlet oxygen and superoxide in the breakdown of pigments and endogenous antioxidants. Plant Physiol., 83: 278-282. PMID: 16665236

Yamasaki, H. and S.C. Grace, 1998. EPR detection of phytophenoxyl radicals stabilized by zinc ions: evidence for the redox coupling of plant phenolics with ascorbate in the $\mathrm{H}_{2} \mathrm{O}_{2}$-peroxidase system. FEBS Lett., 422: 377-380. PMID: 9498820333

Yazbeck, C., W. Kloppmann, R. Cottier, J. Sahuquillo and J. Debotte et al., 2005. Health impact evaluation of boron in drinking water: a geographical risk assessment in northern France. Environ. Geochem. Hlth., 27: 419-427. PMID: 16237598

Yermiyahu, U., A. Ben-Gal, R. Keren and R.J. Redi, 2008. Combined effect of salinity and boron on plant growth and yield. Plant Soil, 304: 73-87. DOI: 10.1007/s11104-007-9522-z

You, C.F., A.J. Spivack, J.M. Gieskes, R. Rosenbauer and J.L. Bischoff, 1995. Experimental study of boron geochemistry: implications for fluid processes in subduction zones. Geochim. Cosmochim. Ac., 59: 2435-2442. DOI: 10.1016/0016-7037(95)00137-9

Zheng, W. and S.Y. Wang, 2001. Antioxidant activity and phenolic compounds in selected herbs. J. Agric. Food Chem., 49: 5165-5170. PMID: 11714298 